\title{
Is Top Executive Compensation Really Sticky in China?
}

\author{
Changzheng Zhang ${ }^{1, a}$, Yuefan $\mathrm{Lv}^{1, \mathrm{~b}^{*}}$ and Xin $\mathrm{Mu}^{1, \mathrm{c}}$ \\ ${ }^{1}$ Xi'an University of Technology, School of Economics \& Management, Xi'an China \\ azcz7901@163.com, b ${ }^{*} 561245907 @ q q . c o m,{ }^{c} 18706718018 @ 163 . c o m$
}

\begin{abstract}
Keywords : Managerial power; Pay-performance Sensitivity(PPS); Executive compensation; Compensation Stickiness; Corporate governance
\end{abstract}

\begin{abstract}
The current literature documents that executives are rewarded for performance increases but are not penalized to the similar extent for performance decreases, especially it seems to be supported in China more strongly. However, in contrast with current literature, we find no significant asymmetry in pay-performance sensitivity (PPS) of executives in China. Drawing on the insights of managerial power and principal-agent theory, taking the Chinese listed manufacturing companies over the year of 2011-2013 as the research sample, the paper investigates the existence of stickiness of PPS of executives at present. By adopting the method of multiple regression linear analysis based on OLS, empirical analysis has proved that though managerial power still has a negative manipulation effect on executive PPS to some degree no matter how firm performance changes, executive PPS always keeps being equivalently positive and thus the asymmetry in executive PPS has disappeared statistically for Chinese listed manufacturing companies. It can be concluded that corporate governance quality, often heavily underestimated in China by both scholars and business circles, has realized substantial improvements, and the monitoring and decision-making role of the shareholders and the board has been growing steadily. Limitations and future research focuses are provided.
\end{abstract}

\section{Introduction}

The relationship between firm performance and executive pay has been one of the most widely studied questions in the executive compensation literature. A substantial theoretical literature develops optimal executive compensation contracts that link pay to variations in firm performance as a means of aligning the incentives of executives (the "agents") with the interests of shareholders (the "principals"). This theoretical literature has spawned numerous empirical tests of the presence, form and strength of the relationship between executive compensation and firm financial performance, which can be termed as pay-performance sensitivity (PPS), a critical component of executive compensation contract.

Just as mentioned above, a large body of research, both theoretical and empirical, has investigated magnitudes and determinants of PPS of top executives. There are mainly two perspectives in investigating the issue of PPS, i.e. principal agency theory and CEO discretion theory. Almost all existing studies based on the managerial power theory have confirmed the stickiness of PPS across the world. However, except for a study conducted by Fang Junxiong $(2009)^{[1]}$, very limited research has reached this special topic in China. Though Fang Junxiong (2009) ${ }^{[1]}$ argued the asymmetry of PPS, we still have no enough evidence to make such a conclusion that the stickiness of PPS does exist in China. What is more, with the rapid development of corporate governance practices, we expect that the stickiness of PPS should have been weakened to a large degree.

Therefore, the paper aims to investigate the existence of the asymmetry of PPS relative to firm performance based on the managerial power approach. We argue that due to the improvement of corporate governance quality in China, especially the quality of executive compensation practices, the asymmetry of PPS should have disappeared or at least, decreased significantly. Since no one knows exactly whether the stickiness of PPS of top executives in China at present still exists or not, it is an initiative to do this job. 


\section{Literature Review and Hypotheses}

In the existing literature, rich research has been done on the relationship between executive compensation and company performance. Both agency theory and managerial power theory recognize that a properly functioning board can ensure effective compensation outcomes, however, managerial power theory emphasizes that board members are highly susceptible to influence by the CEO giving existing corporate governance practices. Therefore, managerial power theory explains and claims that the lack of pay performance links found in the literature as being the result of the power executives have over boards (Bebchuk and Fried, 2004) ${ }^{[2]}$.

Rosen $(1992)^{[3]}$ reviewed empirical findings on executive compensation. Summarizing the existing theory, he concluded that the PPS of the top executives was around 0.1 . This indicated that if the performance of the firm went up with 10 percent, the executive compensation went up with 1 percent. Hall and Liebman (1998) ${ }^{[4]}$ also measured the PPS for the CEOs of the 478 largest publicly firms. They found that the biggest part of the PPS was caused due to changes in value of these stocks and stock options. In fact, they argued that the effect on CEO wealth due to changes in value of their portfolio was fifty times larger than the effect of salary and bonus changes on their wealth.

In Australia, evidence with respect to the relationship between executive compensation and performance is mixed. Variation in these results may be derived from a number of factors including sample size, sample period, the choice of control variables and statistical modeling. Izan et al. $(1998)^{[5]}$, O'Neill and Iob (1999) $)^{[6]}$ and Fleming and Stellios $(2002)^{[7]}$ find no relationship between total CEO cash compensation and performance. In contrast, Merhebi et al. (2006) ${ }^{[8]}$ found a significant pay performance relationship when performance is measured based on total shareholder return.

The new trend in PPS research has emerged that there is an asymmetric PPS relative to different firm performance, which has been confirmed by much literature. May H. Zhang (2008) ${ }^{[9]}$, as one typical example, examined whether CEO cash compensation had an asymmetric relation with firm performance such that CEO was not punished for poor firm performance. These results supported the conclusion that CEO was highly rewarded for good performance but not punished for poor performance.

In China, by initiatively taking Chinese listed firms as the sample investigating the issue of PPS of executives, Fang Junxiong (2009) ${ }^{[1]}$ found a fact that executives would improve PPS when firm performance grew, while decrease PPS when firm performance got worse. In other word, there seemingly was a stickiness in PPS of executives compensation in China.

According to our views, with the improvement of the quality of corporate governance in China, PPS of executives will reflect the change of firm performance in general. Of course, managerial power still can have some affect on the setting of executive compensation, no matter firm performance is lower or higher. That is to say, managerial power can lower PPS than the reasonable level in order to maximize executives' interest. However, the magnitude of such an effect can not change willingness of the board to align the interest of executives and the shareholders.

According the discussion above, we have the following two research hypotheses:

H1: No matter performance grows or decreases, PPS of executives is positive.

$\mathrm{H} 2$ : No matter performance grows or decreases, managerial power is negatively with PPS of executives.

\section{Method and Sample}

Sample. Taking Chinese manufacturing listed enterprises of A-share Market in Shenzhen and Shanghai Stock Exchange over 2011-2013 as the subjects to be investigated. 2199 firm-year observations are chosen as the final sample. The comparison results do confirm the validity of the final sample data. Data processing software is SPSS17.0.

Measure. Measure of PPS. PPS is a measure to find out if executives are compensated appropriately according to how well they run the company. we define PPS as follows by adopting 
the ordinary least square method.(Siegel P A, \&Hambrick D C., 2005; Kubo, 2005; Zhao Xi, $2009)^{[10,11,12]}$.

$$
P P S=\frac{\triangle P A Y}{\triangle R O A}
$$

Data. Table 1 provides the descriptive statistics of the research variables in this study. And there are significant relationship between main control variables and managerial power, and also between main control variables and $\triangle \mathrm{PAY}$. all the correlation coefficients are less than 0.5 , whichw means only weak and acceptable multicollinearity issue will occur when regression analysis is carried out.

Table 1. Descriptive results of research variables

\begin{tabular}{|c|c|c|c|c|c|c|c|c|c|c|c|c|c|c|}
\hline Variables & Mean & $\begin{array}{l}\text { Standard } \\
\text { deviation }\end{array}$ & MP & $\triangle \mathrm{ROA}$ & $\mathrm{FS}$ & $\mathrm{OC}$ & IDR & RI & CENT & WEST & Y2011 & Y2012 FA & $\mathrm{OA} \Delta$ & $\triangle \mathrm{PAY}$ \\
\hline MP & 0.37 & 0.15 & 1 & & & & & & & & & & & \\
\hline$\triangle \mathrm{ROA}$ & -0.01 & 0.17 & -.004 & 1 & & & & & & & & & & \\
\hline$\triangle \mathrm{PAY}$ & 72362.46 & 307827.91 & $.051^{*}$ & .003 & 1 & & & & & & & & & \\
\hline FS & 9.57 & .52 & $-.128 * *$ & -.001 & $.135 * *$ & 1 & & & & & & & & \\
\hline OC & 4.47 & 7.13 & $.115^{* *}$ & .011 & -.036 & .000 & 1 & & & & & & & \\
\hline IDR & 0.36 & .09 & $-.054 *$ & -.009 & $-.308 * *$ & .005 & .036 & 1 & & & & & & \\
\hline RI & 0.06 & 0.64 & $-.070 * *$ & -.023 & .011 & .033 & $-.043^{*}$ & .002 & 1 & & & & & \\
\hline CENT & 0.23 & 0.42 & $-.126 * *$ & .024 & $.047 *$ & .013 & .013 & $.046^{*}$ & $-.270 * *$ & 1 & & & & \\
\hline WEST & 0.20 & 0.40 & -.029 & .006 & $-.057 *$ & -.006 & -.018 & -.005 & .001 & -.016 & 1 & & & \\
\hline Y2011 & 0.33 & 0.47 & .014 & $-.060 * *$ & .000 & .021 & .018 & .005 & .000 & .007 & $-.491 * *$ & 1 & & \\
\hline Y2012 & 0.33 & 0.47 & -.007 & .029 & $.149 * *$ & -.006 & $-.146^{* *}$ & $-.057 *$ & -.021 & .036 & $-.142 * *$ & -.005 & & \\
\hline FA & 16.18 & 5.59 & -.006 & .008 & .034 & .019 & -.007 & .020 & -.018 & .023 & .032 & $-.024-.055^{*}$ & 1 & \\
\hline $\mathrm{OA}$ & 0.18 & 0.38 & .018 & $.073 * *$ & $.066 * *$ & $-.047 *$ & .013 & $-.038 *$ & $-.061 * *$ & -.011 & $.140 * *$ & $-.055^{*}-.012$ & -.0031 & \\
\hline
\end{tabular}

Note: *,** respectively indicates the significance level of 0.01 and 0.05 (Two tails); $\mathrm{N}=2199$.

Empirical Model. According to variable definition and research design, a multiple regression model adopting the linear assumption is constructed as Eq.2 (i.e., Model 1) in order to test H1 and $\mathrm{H} 2$.

$$
\begin{aligned}
& \Delta \mathrm{PAY}=\alpha_{1}+\beta_{1} \mathrm{FS}+\beta_{2} \mathrm{OC}+\beta_{3} \mathrm{IDR}+\beta_{4} \mathrm{RI}+\beta_{5} \mathrm{CENT} \\
& +\beta_{6} \mathrm{WEST}+\beta_{7} \mathrm{Y} 2011+\beta_{8} \mathrm{Y} 2012+\beta_{9} \mathrm{FA}+\beta_{10} \mathrm{OA}+\beta_{11} \mathrm{MP}+\beta_{12} \Delta \mathrm{ROA} \\
& +\beta_{13} \mathrm{MP} \times \Delta \mathrm{ROA}+\varepsilon_{1}
\end{aligned}
$$

\section{Results and Discussion}

Regression Results. We respectively carry out regression analysis by adopting Equation 2 with the whole sample, the sub-sample with performance decline and the sum-sample with performance increase (See Table.2). 
Table 2. Regression results of model 1 with different samples

\begin{tabular}{|c|c|c|c|c|c|c|c|c|c|}
\hline & \multicolumn{3}{|c|}{ Whole sample } & \multicolumn{3}{|c|}{$\begin{array}{l}\text { Sub-sample with performance } \\
\text { decline }\end{array}$} & \multicolumn{3}{|c|}{$\begin{array}{l}\text { Sub-sample with } \\
\text { performance increase }\end{array}$} \\
\hline & B & $\mathrm{T}$ & $\mathrm{P}$ & B & $\mathrm{T}$ & $\mathrm{P}$ & B & $\mathrm{T}$ & $\mathrm{P}$ \\
\hline (Constants) & -310246.069 & -2.005 & .045 & -460788.370 & -2.204 & .028 & -707493.140 & -3.025 & .003 \\
\hline FS & 41000.276 & 2.611 & .009 & 61890.824 & -.422 & .004 & 76418.288 & 3.267 & .001 \\
\hline $\mathrm{OC}$ & -1980.687 & -1.737 & .083 & -1934.305 & -.038 & .095 & -1816.426 & -1.151 & .250 \\
\hline IDR & -35868.952 & -.411 & .581 & -51567.397 & 3.313 & .256 & 33896.288 & .269 & .188 \\
\hline RI & -9407.882 & -.749 & .454 & 43818.402 & .438 & .518 & -17197.685 & -1.444 & .149 \\
\hline CENT & -24090.617 & -1.226 & .220 & -10802.227 & .456 & .673 & -58699.111 & -2.008 & .045 \\
\hline WEST & -30881.154 & -1.482 & .139 & -1058.751 & -1.239 & .970 & -94039.861 & -3.138 & .002 \\
\hline Y2011 & 91034.871 & 4.618 & .000 & 89240.609 & -.445 & .001 & 111930.339 & 4.046 & .000 \\
\hline Y2012 & 23748.960 & 1.216 & .224 & 11403.051 & .647 & .662 & 49482.708 & 1.686 & .092 \\
\hline FA & -129.096 & -.088 & .429 & 837.469 & .914 & .648 & -1689.995 & -.736 & .462 \\
\hline $\mathrm{OA}$ & -6048.339 & -.290 & .372 & 24872.217 & 2.899 & .361 & -35169.150 & -1.144 & .253 \\
\hline MP & 22060000.00 & 8.521 & .000 & 63680000.00 & 9.290 & .000 & $\begin{array}{l}33180000.0 \\
0\end{array}$ & 10.161 & .000 \\
\hline$\triangle \mathrm{ROA}$ & 1614251.349 & 9.777 & .000 & 3516096.216 & 9.623 & .000 & $\begin{array}{l}2761914.90 \\
7\end{array}$ & 9.243 & .000 \\
\hline $\mathrm{MP}^{*} \Delta \mathrm{ROA}$ & $\begin{array}{l}-37340000.0 \\
0\end{array}$ & -8.527 & .000 & $\begin{array}{l}-108300000.0 \\
0\end{array}$ & -9.285 & .000 & $\begin{array}{l}-55770000.0 \\
0\end{array}$ & -9.261 & .000 \\
\hline $\mathrm{F}$ 值 & 11.142 & & & 8.929 & & & 10.894 & & \\
\hline Adj-R2 & 0.162 & & & 0.128 & & & 0.139 & & \\
\hline $\mathrm{N}$ & 2199 & & & 1311 & & & 888 & & \\
\hline
\end{tabular}

a. $\triangle$ PAY as dependent variables.

For the whole sample, According to column 2, the change of ROA will lead to a responding positive change of executive compensation. And we can confirm that for sub-samples with performance increase and for sub-sample with performance declined there are still a positive PPS. Therefore, it can be concluded that, no matter how firm performance changes, PPS of executives always keeps positive. H1 holds.

When it comes to the role of managerial power on PPS of executives, the three samples provide the same results. Such a fact indicates that no matter how performance changes, managerial power has its steady positive effect on the change of executive compensation. What is more, the regression coefficient of $M P^{*} \triangle \mathrm{ROA}(\beta 3)$ means the net/partial effect of managerial power on PPS of executives, such a fact further indicates that managerial power can weaken PPS of executives significantly. Therefore, $\mathrm{H} 2$ holds.

Discussion and Implications. The empirical result in this study is somewhat different with the previous studies. This finding is of great meanings both theoretical and practical. Theoretically, we find the substantial improvement of the quality of corporate governance at first time, while practically, the new finding can provide effective practical suggestions for enhancing governance practices. Based on logical analysis, several critical potential causal paths of the improvement of the quality of corporate governance should be paid more attention. 


\section{Conclusions}

According to the theoretical analysis and empirical data, something new has been found out in this paper. First, no matter how firm performance changes, getting better or worse, executive compensation change is significantly positively related to firm performance change, which means PPS of executives does not change with the status of firm performance; Second, no matter how firm performance changes, managerial power stably decreases PPS of executives by improving executive compensation without considering the maximization of firm value. Based on the results, we make the following conclusions.

Both principal-agent theory and managerial power theory can apply to the present setting process of executive PPS to different degrees and under different contexts. Under the condition of performance decline, managerial power theory takes the dominant role, i.e.. Under the condition of performance increase, principal-agent theory takes the dominant role, i.e..

There are still some limitations of this research. First, the measure of managerial power neglects the power derived from industry level features. Future study should attempt more comprehensive measure methods of managerial power and thus get more comprehensive and valid results in this topic. Second, the sample is limited to listed manufacturing companies, Future study should improve the research in this field by designing samples consisting of wider companies and longer time.

\section{Acknowledgements}

This research was supported by Projects of the National Social Science Foundation of China under the Grant "15BGL109", the Scientific Research Foundation of Ministry of Education of the PRC in Humanities and Social Sciences under Grant "14YJA630089" and "13YJAZH123", and the Shaanxi Social Science Foundation under Grant "2014P04", and National Natural Science Foundation of China under Grant "71402136".

\section{References}

[1] Fang Junxiong. Is Top Management Compensation of Chinese Public Companies Sticky?[J] Economic Research Journal, 2009, 3: 110-124. (In Chinese)

[2] Bebchuk, L. A. and J. Fried. Pay without Performance: The Unfulfilled Promise of Executive Compensation[M]. Harvard University Press.2004.

[3] Rosen, S. Contracts and the market for executives[J]. Contract Economics, Cambridge: MA: Blackwell, 1992: 181-211.

[4] Hall, B.J. and Liebman J.B. Are CEOs really paid like bureaucrats[J]. Quarterly Journal of Economics, 1998, 113 (3): 653-691.

[5] Izan, H.Y., B. Sidhu, and S. Taylor. Does CEO pay reflect performance? Some Australian Evidence[J]. Corporate Governance, 1998, 6(1): 39-47.

[6] O'Neill, G., and M. Iob. Determinants of Executive Remuneration in Australian Organizations: An exploratory study[J]. Asia Pacific Journal of Human Resources, 1999, 37 (1):65

[7] Fleming, G. A., and G. Stellios. CEO Compensation, Managerial Agency and Boards of Directors in Australia[J]. Accounting Research Journal 2002: 126.

[8] Merhebi, R., K. Pattenden, P.L. Swan, and X. Zhou. Australian Chief Executive Officer Remuneration: Pay and Performance[J]. Accounting and Finance, 2006, 46(3):481-497.

[9] May H. Zhang. Asymmetric. Pay-for-Performance Sensitivity: Evidence from CEO Cash Compensation, ResearchGate Article No256000058, http://www.researchgate.net/publication/256000058. 2008 
[10] Siegel P A, Hambrick D C. Pay disparities within top management groups: Evidence of harmful effects on performance of high-technology firms[J]. Organization Science, 2005, 16(3): 259-274.

[11] Kubo K. Executive compensation policy and company performance in Japan[J]. Corporate Governance: An International Review, 2005, 13(3): 429-436.

[12]Zhao Xi, Du Yupeng. The Impact of Corporate Governance on Sensitivity of Executive Compensation Incentives[J]. Soft Science Journal,2009, 23(11): 92-95. (In Chinese) 